\title{
'PECULIARLY WOMAN'S CAUSE': FEMINISM, RACE, AND THE STRUGGLE FOR EQUALITY
}

\author{
Jonathan H. Earle
}

Julie Roy Jeffrey. The Great Silent Army of Abolitionism: Ordinary Women in the Antislavery Movement. Chapel Hill: The University of North Carolina Press, 1998. xii + 311 pp. Illustrations, notes, bibliography, and index. $\$ 45.00$ (cloth); $\$ 18.95$ (paper).

Louise Michele Newman. White Women's Rights: The Racial Origins of Feminism in the United States. New York: Oxford University Press, 1999. vii +261 pp. Illustrations, notes, selected bibliography, and index. $\$ 49.95$ (cloth); \$19.95 (paper).

In 1838, the issue of race nearly destroyed the newly-formed Female AntiSlavery Society of Fall River, Massachusetts. The Society, founded by women from some of the city's most respected white families, was busy organizing lectures, signing petitions, and raising money when three free black womenalready regular attendees at meetings-applied for membership. According to Elizabeth Buffum Chace, a founding member of the Society, few of the white members objected to black women attending the meetings. "But they did not think," Chace recorded in her diary, "it was at all proper to invite them to join the Society, thus putting them on an equality with ourselves." The Society survived, however, after Chace and her sister "maintained [their] ground" and the "respectable young colored women" were invited to become full members. ${ }^{1}$

The struggle to integrate the Female Anti-Slavery Society of Fall River points directly to the major themes of two important new monographs on women and race, Julie Roy Jeffrey's The Great Silent Army of Abolitionism and Louise Michele Newman's White Women's Rights. Both books mine substantial and original bodies of primary sources, are lucidly written, and build on the excellent scholarship of the past quarter century. Yet each book points in an entirely different direction. Jeffrey recounts the Fall River incident as part of a larger effort to correct a myopic tendency by historians of the antislavery movement to focus on men, even as they claim (as many of the abolitionists themselves did) how vital women were to the abolitionist project. By concen- 
trating on unpublished letters from ordinary abolitionist women, often left languishing in the well-mined collections of prominent male abolitionists, as well as diaries and scattered organizational records, Jeffrey illustrates how women's day-to-day work kept abolitionism alive. In her telling of the Fall River incident, Jeffrey points to a largely unexplored contradiction: why antislavery women could believe they were so intimately linked with and attuned to enslaved black women, especially mothers, and not to free black members of their own communities. She writes how white women activists often spoke of a "special sensitivity, based on gender" to the plight of slave women, or as one group of Ohio abolitionists put it, "the cry of the sable mother" (p. 65).

Newman, whose book is largely concerned with the years 1870-1920, takes as her subject feminism itself. Her provocative thesis goes well beyond the older view that certain white feminists held racist or ethnocentric ideas and attempts to isolate a racial (and, indeed, racist) component within feminism itself. It thus joins a growing literature on "whiteness" and the formation of racial identity pioneered by historians like David Roediger and Noel Ignatiev, adding a missing female element to their examinations of the links between racism and America's democratic movements. Much of Newman's argument rests on her explications of nineteenth-century evolutionary models, and how they affected the development of feminist ideology. In chapters focusing on topics as diverse as the Indian reform movement of the 1880s, the popular response to May French-Sheldon's African Safari in the 1890s, and Margaret Mead's failure to overcome her cultural ethnocentrism while attacking Victorian ideas of evolutionary assimilation, Newman sets out a detailed explanation of how feminism emerged as a racialized theory of gender oppression.

$$
* * *
$$

Perhaps the most rewarding of Jeffrey's many contributions here is the subtle and complex portrait of the grassroots army of women-black and white-who sustained the antislavery movement over the decades preceding emancipation. The labors Jeffrey records include many of those familiar in previous works on antislavery: public lecturing, editorial writing, and the harboring of fugitive slaves. But she also sheds light on numerous other, more hidden laborers as well, including church quilters, fair impresarios, and nurses.

The opening chapters of The Great Silent Army of Abolitionism focus on how women were recruited to the cause and how they acquired the skills and attitudes that moved them beyond the traditional conventions of middle-class life. The book breaks new ground in the chapter devoted to women's antislavery fairs, a vastly understudied part of the abolitionist movement. 
Using evidence like the records of the Dover [N.H.] Sewing Circle, newspaper clippings, and letters, Jeffrey shows how women's fairs helped the antislavery movement survive while also bringing women outside their traditional sphere into the commercial world. It has been almost 70 years since Gilbert Barnes questioned the centrality of the Garrisonian wing of abolitionists, in favor of a wider movement led by evangelical Midwesterners. ${ }^{2}$ Barnes' argument-that a large percentage of abolitionists came to the movement via the religious revivals of the Second Great Awakening-was the first step in widening the scope of abolitionist study beyond the Boston suburbs. The flood of abolitionist historiography inspired by the civil rights movement deepened our understanding of the movement, especially in regard to African American contributions. And historians of the American working class have added vital studies of the antislavery rank and file, painting a picture of the abolitionist movement that was more broadly-based and less exclusively evangelical and middle class than was previously supposed. ${ }^{3}$ By focusing on ordinary women, Jeffrey has added dramatically to a fuller understanding of why people became abolitionists, the labor they performed, and the ways they sustained the movement for three decades in the face of uncooperative families, severe setbacks, and even violence. As a final corrective, we still need studies that more fully explain why people chose to oppose slavery, including those who would never call themselves "abolitionists" (a synonym for "fanatics" among a vast majority of Americans). Barnes came to his revisionism after discovering a mysterious trunk in an Ohio attic containing the unpublished correspondence of Angelina Grimké and Theodore Weld; Jeffrey's sewing circles and antislavery fairs, though never actually "lost," represent the same type of historical treasures.

Jeffrey takes as her epigraph a famous quotation by Frederick Douglass: "When the true history of the antislavery cause shall be written, women will occupy a large space in its pages, for the cause of the slave has been peculiarly woman's cause." Douglass's sentiments were echoed, time and again, by others toiling to rid the nation of slavery. "The Anti-Slavery cause cannot stop to estimate where the greatest indebtedness lies," declared William Lloyd Garrison in 1847, "but whenever the account is made up, there can be no doubt that the efforts and sacrifices of WOMEN, who helped it, will hold a most honorable and conspicuous position." It didn't happen. Even though women antislavery activists tirelessly organized lecture series (in many cases taking the stage themselves), circulated newspapers, raised money, signed petitions, housed fugitive slaves, sewed quilts, and supported antislavery political parties, men took most of the credit for ending slavery. And despite a passage in nearly every modern U.S. history textbook about the centrality of women in the antislavery movement, their efforts are often subsumed under 
several paragraphs about the better-known (and better documented) actions of Garrison, Douglass, or Abraham Lincoln. This disconnect between the roles women played in the antislavery movement and in later written histories continues into the present day. The best-selling work of non-fiction on the antislavery movement last year (by a vast amount) was a biography, not of Angelina Grimké or Harriet Beecher Stowe, but of William Lloyd Garrison. Henry Mayer's All On Fire: William Lloyd Garrison and the Abolition of Slavery dwarfed the sales of all other books on related subjects, including the late Paul Goodman's Of One Blood: Abolitionism and the Origins of Racial Equality and Albert J. Von Frank's The Trials of Anthony Burns. And despite Garrison's own views, as quoted above, Mayer devotes scant pages to women in the movement (I am normally not a member of the "page counting" school of book reviewing, but the near total absence of women in Mayer's lengthy book tempted me to matriculate). Jeffrey's explanation for this type of omission is compelling: part of it is the sources (sewing circles didn't usually keep voluminous records), and part of it is due to the women's tendency to write themselves into a separate sphere. Only a very few abolitionist women, Jeffrey argues, were willing to abandon woman's moral voice for feminist egalitarianism. In most cases, Jeffrey shows, a strong commitment to abolitionism severely limited women's ability to challenge traditional gender arrangements-many activists found that their female "moral voice" against the evils of slavery was too potent a weapon to give up. And besides, she reminds us, to embrace abolitionism was an inherently radical act by itself, one that challenged the political, economic and social status quo in addition to traditional gender norms. The bitter (and often violent) opposition to the movement in the South and within the federal government provides ample evidence of the movement's ability to inspire fear and hatred among the supporters of slavery.

Louise Michelle Newman's book also begins as a historiographic corrective, but then it veers off into fully revisionist territory. Although they contain overlapping actors and themes, White Women's Rights and The Great Silent Army of Abolitionism at first seem to be about two different countries. It's as if, in a movie sequel, the heroes from the earlier film were lit from below to give them a sinister, malevolent air. Where Jeffrey's women petition, speak out, and sew out of a deep-seated sympathy for the enslaved, Newman's postbellum white suffragists stress their own racial and cultural superiority to justify their enfranchisement. But while previous studies have focused on the ethnocentrism or racism of particular women and feminists (it is certainly not difficult to find enough racist quotations to fill several volumes), Newman accuses the ideology of feminism itself of being intrinsically racialized, even built on white supremacy. The argument here is too subtle to suggest an unholy 
alliance between the followers of Elizabeth Cady Stanton and Nathan Bedford Forrest, but we nearly get there just the same.

It is difficult to argue with several of Newman's assertions. Namely, that in the late nineteenth and early twentieth centuries white women in the suffrage movement formulated their views of equality within the context of highly charged debates on race, and exploited contemporary "scientific" findings that Anglo-American Protestants stood atop the cultural and biological hierarchy. She is at her best when she analyzes and links the various women's organizations that pressured the U.S. Government to outlaw lynching, change its Indian policies, or opened settlement houses to introduce patriarchal, "American" domesticity to other races. Instead of feeling capable of moral superiority because of a religious conversion or an ability to empathize with oppression, Newman suggests that white women cited an inherently racespecific trait to justify their benevolence. Blending religious conviction, science, and political ideology, Newman writes, white proponents of women's rights "helped create new roles for themselves that explicitly maintained the racial hierarchies that were based on the presumption that Anglo-American Protestants were culturally, as well as biologically, superior to other peoples" (p. 7). This sets up an interesting paradox, one that should provoke considerable debate: that the very key to white women's own racial advancement (and the reason they were justified in staking a claim to voting rights) was patriarchy. In other words, white women's rights activists blamed nonwhites' stunted social progress on the absence of American-style, middleclass gender relations. So at the same time they were formulating a critique of patriarchal gender relations, these same women urged a healthy infusion of patriarchy to "elevate" inferior, non-white cultures (and spare their women "primitive" horrors like foot binding, nose boring and bride sale). This hypocrisy, Newman writes, severely limited white women's ability to expose and critique racism and sexism in American culture.

While it is undeniably true that white women developed their arguments for sexual equality in a time of the nation's nadir in race relations (a time of record lynchings of African Americans, Jim Crow laws, and imperialism), this does not necessarily undermine the entire feminist project. Thomas Jefferson wrote the Declaration of Independence and at the same time deeply believed in the superiority of the white race, in a climate where these beliefs were rarely challenged. And abolitionist racial egalitarian ideology (even though embraced by only a small proportion of abolitionists) emerged out of a Jacksonian culture that celebrated anti-abolitionist and anti-black mob activity. The question is not whether Charlotte Perkins Gilman or Mary Roberts Coolidge were "racists" by our twenty-first-century standards; they were, and we already knew that. Today a college student is as likely to learn about Gilman's ties to the eugenics movement as her contributions to feminism. 
Newman acknowledges in her introduction that she fears her findings could mask racism in the culture at large or even aid the conservative backlash against the women's movement. Yet her largest disservice is her slighting of those feminists who did overcome the withering racism of the day and to form meaningful political associations with black leaders like Ida B. Wells, Frances W. Harper, or the free black members of the Female Anti-Slavery Society of Fall River. This is part of Jeffrey's story, but not Newman's.

In many ways, Newman's feminists resemble David Roediger's antebellum white workers, who fashioned new "white" identities to compensate for their exclusion from economic and political power. In numerous influential essays, Roediger presents white workers-even those who opposed slavery by signing petitions or becoming free soilers-as racist and land-hungry, legitimizing slavery by striving only to limit its expansion. ${ }^{4}$ But in his attempt to censure free soilers and workers for their racist views (ideas they unfortunately shared with a vast majority of nineteenth-century Americans), he neglects the contributions many of them made in the political struggle against slavery in the 1840s and 50s. Restricting slavery was, for many Northerners, seen as a first step towards its eradication. Is it fair to say one could only sincerely oppose slavery by adopting twenty-first-century style, anti-racist principles? Similarly, why should we demand (or even expect) nineteenthcentury feminists to overthrow existing and racist evolutionary models in their own quest for equality? Finally, does racism within a movement undermine and destroy the entire project, be it feminism or antislavery? Like it or not, movements exist in the real world and, to achieve their goals, have to interact with larger societies that harbor racial, gender, and class-based biases. To conclude that feminism-a belief in the social, political, and economic equality of the sexes-is bankrupt because it was tainted by (or even infused with) racism somehow misses the point.

The transition from agitation (during the abolitionist movement) to organization (after the passage of the Fifteenth Amendment) forced suffragists to alter their political style and content in significant ways. As abolitionists, they were often trained (and encouraged) to express their ideas in the most radical forms possible. As organizers and feminists, they had to be far more pragmatic, especially in the conservative climate of late nineteenth-century America. This is not to let people like Elizabeth Cady Stanton, who famously complained that "Patrick and Sambo and Hans and Yung Tung" could make laws for Lucrecia Mott and Anna Dickinson, off the hook. Convincing men, who selfishly grasped the reigns of power, to expand rights-even human rights-to women was an extremely daunting task. That women's suffrage wasn't accomplished by pure and anti-racist rhetoric and means is unfortunate, but not surprising. 
Even with all their overlap in subject, ideology, and emphasis, Jeffrey and Newman point the field of women's history in divergent directions. Jeffrey's book, an example of traditional women's history, will make the next biography of Garrison or Douglass appear ludicrous for not emphasizing the contributions of ordinary women abolitionists. Newman, with her explicitly post-modern theoretical analysis, hopes her work will help spur alliances between movements for feminism, antiracism, multiculturalism, postcolonialism, and anticapitalism. She concludes her book by urging that we, twenty-first-century Americans "come to terms with the past in order to develop new strategies for the future" (p. 185). There is no doubt much to come to terms with, much of it very, very bad. Yet we also have the words of Angelina Grimké, written in her address to the women of the South: "[G]reat numbers cannot bear the idea of equality," she wrote. "Prejudice against color is the most powerful enemy we have to fight with in the North." ${ }^{5}$ It was precisely this strain of antiracism, rare as it may have been, that allowed a racially-integrated Female Anti-Slavery Society of Fall River to continue its work for abolition.

Jonathan H. Earle, assistant professor of history, University of Kansas, is the author of The Routledge Atlas of African American History (2000) and The Undaunted Democracy: Jacksonian Antislavery and Free Soil, 1828-1854 (forthcoming from the University of North Carolina Press).

1. Shirley J. Yee, Black Women Abolitionists: A Study in Activism, 1828-1860 (1992), 93.

2. Gilbert H. Barnes, The Antislavery Impulse, 1833-1844 (1933).

3. Edward Magdol, The Antislavery Rank and File (1986); John B. Jentz, "Artisans, Evangelicals and the City: A Social History of Abolition and Labor Reform in Jacksonian New York," (Ph.D. diss., CUNY, 1977).

4. David Roediger, The Wages of Whiteness: Race and the Making of the American Working Class (1991).

5. Larry Ceplair, ed., The Public Years of Sara and Angelina Grimké: Selected Writings, 18351836 (1991), 71-3. 